Marek Jakubiec

\title{
FILOZOFIA WYBORU SØRENA KIERKEGAARDA I BARUCHA SPINOZY A TEORIA PRAWA
}

\section{WPROWADZENIE}

Możliwość dokonywania wyborów powiązana jest bezpośrednio z istnieniem wolności woli. Dzieła poświęcone tej problematyce zajmują istotne miejsce w historii filozofii i literatury europejskiej. Człowiek pojmuje siebie jako istotę wolną i o wolność jest gotów walczyć. Jest ona bowiem istotnym elementem jego egzystencji, dzięki któremu posiada on własną tożsamość ${ }^{1}$. Niemniej jednak, każdy posiada specyficzną wizję wolności. Może ona być postrzegana przede wszystkim jako wolność od (ucisku, zależności od innych etc.) lub jako możliwość dokonywania wyborów, swobodnego podejmowania decyzji, a więc przede wszystkim wolność do.W opinii wielu myślicieli fakt istnienia wolności był kluczową kwestią warunkującą sensowność życia ludzkiego. Inni podejmowali z nimi polemikę, twierdząc, że człowiek wcale nie jest wolny i aby móc cieszyć się istnieniem, trzeba ten fakt zaakceptować2.

W artykule zostaną zaprezentowane poglądy dwóch filozofów, którzy podjęli refleksję na ten temat. Wizja Barucha Spinozy, negującego wolność

${ }^{1}$ Zob. G. Hołub, Wolność należy do Ciebie? Pomiędzy obiektywnym a subiektywnym rozumieniem dobra, „Cywilizacja” 2004, nr 10, s. 67.

${ }^{2}$ Przykładem takiego filozoficznego dwugłosu mogą być filozofowie, których poglądy zostaną przedstawione w tej pracy. Dla Kierkegaarda wolność jest pewnym faktem, z kolei Spinoza pojmuje ją zupełnie inaczej. 
dokonywania wyborów i kształtowania własnej egzystencji, przeciwstawia się tej prezentowanej przez Sørena Kierkegaarda, który akcentuje konieczność podejmowania przez jednostkę decyzji, co - jego zdaniem - jest niezbędne do osiągnięcia stanu egzystencji autentycznej. Obok pojęć człowieka i jego wolności oraz dobra i zła, kluczowym będzie pojęcie Absolutu, Boga. Dla koncepcji omawianych myślicieli Bóg, rzecz jasna różnie rozumiany, stanowi postać konstytuującą ich teorie. Według Kierkegaarda człowiek spełnia się dopiero wtedy, gdy zwróci się ku Bogu, odkryje Jego istnienie. Bez tego życie nie jest świadomą egzystencją; człowiek nie szukając transcendentnego Boga tworzy sobie immanentne bożki - są to rozmaite przyjemności i uciechy życia, co jest widoczne zwłaszcza na tak zwanym etapie estetycznym, stanowiącym według Duńczyka jedno ze „stadiów” życia ludzkiego.

Inaczej pojmuje Boga Baruch Spinoza. Dla niego Absolut jest substancją tworzącą całą rzeczywistość. Ważniejsze jednak od samej koncepcji Boskiej natury są wnioski, jakie wyciąga Spinoza. Zostaną one poddane analizie $\mathrm{w}$ trzecim rozdziale.

Po zaprezentowaniu najważniejszych kwestii związanych z filozofią wyboru, jakie możemy odnaleźć w twórczości rzeczonych myślicieli, podjęta zostanie próba uzasadnienia tezy głoszącej, że owe rozważania filozoficzne mogą być niezwykle istotne dla szeroko pojętych nauk prawnych. Tworząc prawo, społeczeństwo zakłada, że normy prawne prędzej czy później zostaną złamane, stąd przewidywane są rozmaite sankcje. To z kolei jest wynikiem presupozycji dotyczącej wolności człowieka - konkretnie: przyjmującej istnienie wolnej woli u większości ludzi, którzy za swoje czyny ponoszą odpowiedzialność.

Czy jednak przyjęcie takiego założenia jest uzasadnione? A może jest skutkiem iluzji wolności podejmowania decyzji, w której wszyscy tkwimy? Niezwykle pomocna w poszukiwaniu odpowiedzi może okazać się analiza rozważań wspomnianych myślicieli. Będzie ona stanowić główny przedmiot rozważań w tym artykule.

\section{OBRAZ EGZYSTENCJI LUDZKIEJ I ROLA WOLNOŚCI U SøRENA KIERKEGAARDA}

2.1. ŹRódeA MYŚli DUŃSKIEgo Filozofa. Wielu badaczy twórczości Kierkegaarda uważa, że jego myśl została ukierunkowana 
przez wydarzenia i mity rodzinne ${ }^{3}$. Bez wątpienia miały one istotne znaczenie, choć oczywiście kluczowe było zapoznanie się z myślą filozoficzną, przede wszystkim Friedricha Wilhelma Schellinga i Friedricha Adolfa Trendelenburga. Znalazło to odbicie w niezwykle krytycznej wobec heglizmu postawie filozofa. Jej przejawem było wydanie książki pod tytułem Albo - albo, prezentującej dwa typy życia: estetyczny, opierający się na dążeniu do przyjemności oraz braku poczucia odpowiedzialności za czyny, i etyczny, w którym jednostka podporządkowuje się wymogom społeczeństwa ${ }^{4}$. Znamienne jest, że w swojej polemice z filozofią Hegla, Kierkegaard sięga po jego typ rozumowania oparty na triadzie: teza - antyteza - synteza, oczywiście modyfikując go i dostosowując do własnych potrzeb. Jego „egzystencjalna dialektyka" nie dotyczyła całego systemu (np. społeczeństwa); zamiast holistycznego ujęcia Kierkegaard skupia się na jednostce ludzkiej ${ }^{5}$, ukazując dramat jej istnienia i konieczność stawania wobec konieczności dokonywania wyborów, często niezwykle trudnych. Stąd owa alternatywa i wolność decyzji wyrażająca się w słowach „albo - albo" nie jest przez niego rozumiana do końca pozytywnie.

2.2. WARUNKI EGZYSTENCJ LUdZKIEJ. Kierkegaard jako myśliciel chrześcijański akcentuje rolę wiary w życiu człowieka. Bóg i stojąca przed Jego Obliczem jednostka to kluczowe pojęcia jego filozofii ${ }^{6}$. Człowiek, jako istota wolna, zmuszony jest do podejmowania różnych decyzji, niejednokrotnie brzemiennych w skutkach. Owa wolność daje jednak także wiele możliwości pozytywnych. Do nich z pewnością należy zwrot ku Bogu, który stanowi kluczowy moment w dojrzewaniu człowieka do autentycznego życia. Oczywiście można poprzestać na życiu nastawionym tylko na przyjemność, to jednak z czasem prowadzi do uświadomienia sobie przez jednostkę nędzy egzystencji i rozpaczy. Pojawia się więc pytanie: czy właściwie człowiek jest wolny, skoro prędzej czy później, niezależnie od swej

${ }^{3}$ Zob. K. Toeplitz, Kierkegaard, Wiedza Powszechna, Warszawa 1975, s. 19-20.

${ }^{4}$ Więcej na temat tej (jednej z najważniejszych) publikacji Duńczyka w części trzeciej niniejszego rozdziału.

${ }^{5}$ Zob. A. Szwed, Między wolnością a prawdą egzystencji. Studium myśli Sørena Kierkegaarda, Universitas, Kraków 1991, s. 30.

${ }^{6}$ Zob. K. Toeplitz, Kierkegaard, dz. cyt., s. 37. 
woli, niejako „pod presją” rozpaczy stanie wobec konieczności zmiany sposobu prowadzenia swojego życia?

W tym miejscu warto pochylić się nad Kierkegaarda wizją człowieka. Uznaje on, że niezwykle istotne jest samopoznanie, jakiego dokonuje jednostka ${ }^{7}$. Początkowy etap tego procesu ${ }^{8}$ polega na wstępnym rozpoznaniu siebie, co jest konieczne dla określenia podstaw swej egzystencji oraz własnej tożsamości. Ponieważ jednak w wizji Kierkegaarda człowiek stoi „w obliczu Boga", procesu poznania siebie nie da się ukończyć bez odniesienia do Niego. To właśnie dzięki temu zwrotowi następuje oczyszczenie człowieka z iluzji, w których dotychczas żył. Poprzez określenie swego „ja” przed Bogiem, zyskuje ono nową jakość - jest już nie tylko „ludzkim ja”, lecz także „teologicznym ja" ${ }^{10}$. Swego rodzaju przeciwieństwem istnienia przed Bogiem jest stan grzechu, a więc rezygnacja z trwania przy dobru i wybór zła.

Kierkegaardowska wizja ludzkiej natury jest daleka od koncepcji monistycznych. Wyróżnia on w niej bowiem trzy sfery (nie określając jednak szczegółowo relacji, jakie między nimi zachodzą). Ciało, dusza i duch, bo o nich mowa, konstytuują byt ludzki ${ }^{11}$. Zastanawia - z racji identyfikacji Duńczyka z chrześcijaństwem - wyróżnienie enigmatycznego „ducha” obok ciała i duszy. Zostaje on określony jako sfera, która zapewnia złączenie duszy i ciała w pewną jedność. Nie jest jednak ich skutkiem czy wypadkową. Człowiek jest bowiem w swej istocie duchem, nawet jeśli ów duch istnieje w sposób ukryty ${ }^{12}$. Właśnie do ducha przynależy atrybut woli, która umożliwia dokonywanie wyborów - dzięki temu zaś możliwe jest przejście do kolejnych etapów egzystencji.

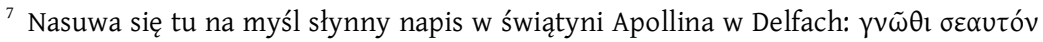
(„Poznaj samego siebie”). Kierkegaard często czynił nawiązania do antycznej kultury greckiej, zwłaszcza w swoim Dzienniku.

${ }^{8} \mathrm{Na}$ fakt, że jest to proces, a nie jednorazowy akt, zwraca uwage Antoni Szwed. Zob. np. A. Szwed, dz. cyt., s. 30.

${ }^{9}$ Zob. K. Toeplitz, Kierkegaard, dz. cyt., s. 37.

${ }^{10}$ Zob. S. Kierkegaard, Choroba na śmierć, przeł. J. Iwaszkiewicz, Wydawnictwo Homini, Kraków 2008, s. 236-237.

${ }^{11}$ Zob. A. Szwed, dz. cyt., s. 32.

${ }^{12}$ Zob. tamże. 
W wizji Kierkegaarda niezwykle ważnym elementem życia ludzkiego jest wiara, łącząca sprzeczności ${ }^{13}$. Życie jest bowiem dla myśliciela sprzecznością: z jednej strony człowiek styka się z wieczną prawdą, a z drugiej z wielością istnień, których nie potrafi pojąć. Istotny jest także jego czasowy aspekt; człowiek, jako egzystujący duch, zawsze staje się, a nigdy nie jest ${ }^{14}$. U podstaw owego stawania się podmiotu leży wolność.

Mimo swoistego uzależnienia człowieka od Boga człowiek pozostaje wciąż istotą wolną. Będzie to lepiej widoczne po dokładniejszym przedstawieniu wizji egzystencji ludzkiej, jaką posiadał Kierkegaard.

2.3. WOBEC DOBRA I ZŁA - KONIECZNOŚ́́ PODJĘCIA DECYZJi I ETYCZNEGO SAMOUJAWniEnia Się. Søren Kierkegaard jest autorem słynnego „podziału” ludzkiej egzystencji na trzy „typy”: estetyczny, etyczny i religijny. Są to tak naprawdę trzy możliwości postępowania człowieka, stanowiące pewne etapy na drodze ku Bogu. Każdy z nich to pewien zamknięty okres w życiu jednostki. Tym, co sprawia, że człowiek aktualnie przeżywa określone stadium, jest jednak nie tylko jego sposób życia (dziś powiedzielibyśmy „styl”), lecz także stosunek (lub jego brak, który wszakże też jest pewnym stosunkiem) do Absolutu.

Przejście z jednego etapu do drugiego nie następuje automatycznie, ewolucyjnie, lecz jest wynikiem podjętej przez człowieka decyzji. Stanowi ono tak naprawdę skok w nową rzeczywistość. Najwyższe stadium rozwoju egzystencji ${ }^{15}$, religijne, nie jest jedynie szczytem rozwoju, lecz także jego celem. Stosunek człowieka do Absolutu jest kluczowy, stanowi warunek "autentycznej egzystencji" ${ }^{16}$. Poprzednie etapy, estetyczny i etyczny, są przejściowe, nie stanowią ostatecznego celu, gdyż nie prowadzą

${ }^{13}$ Zob. S. Kierkegaard, Dziennik, przeł. A. Szwed, Wydawnictwo Naukowe KUL, Lublin 2000, s. 94.

${ }^{14}$ Zob. A. Szwed, dz. cyt., s. 45.

${ }^{15}$ Jak zostało już zaakcentowane, rozwoju nie należy pojmować jako procesu ciągłego; w tym przypadku nie ma bowiem ciągłości, a wręcz przeciwnie: pojawia się pewne zerwanie, „skok” przejawiający się w wyborze, w wyniku którego człowiek rezygnuje ze swego dotychczasowego życia.

${ }^{16}$ Celowo użyłem sformułowania charakterystycznego dla twórczości Heideggera. Wydaje się bowiem, że istnieje pewna analogia między odniesieniem do Absolutu w wizji Kierkegaarda a stosunkiem do śmierci (sein-zum-Tode) u Heideggera. 
bezpośrednio do wiary ${ }^{17}$.

Myśliciel z Kopenhagi, przedstawiając każde ze stadiów, ukazuje nam wiele różnych możliwości egzystencji w jego ramach. Niewątpliwie jest to kwestia istotna, gdyż wskazuje nie tylko na uniwersalność poruszanej problematyki (dotyczy ona każdego, bez względu na jego osobiste przeżycia), lecz także ukazuje krytyczną analizę wszystkich typów życia, co ma być wskazówką stwierdzającą konieczność podjęcia ryzyka drogi ku Bogu, która nie jest do końca racjonalnie uzasadnialna.

Pierwszym etapem egzystencji (choć nie jest to najtrafniejsze określenie $\left.{ }^{18}\right)$ jest stadium estetyczne. Należy je określić jako „najniższe” ze wszystkich $^{19}$. Przed jego dokładniejszym opisem warto pochylić się krótko nad Kierkegaardowskim rozumieniem estetyki. Nie jest ona dla niego dziedziną rozważającą to, co piękne czy wiążące się ze sztuką. Antoni Szwed zwraca uwagę na fakt, że słowo „estetyczny” ma u Kierkegaarda znaczenie bardziej

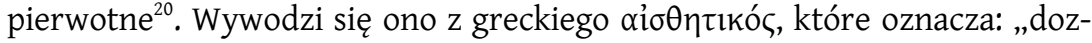
nany”, „zmysłowy”. Cała egzystencja człowieka estetycznego polega zatem na pragnieniu doznawania przyjemności i poszukiwaniu bodźców ją wywołujących. Piękno nie jest przez estetę postrzegane jako coś wspaniałego, doskonałego czy wręcz metafizycznego; przeciwnie, jest dla niego jedynie źródłem przyjemności, zaspokojeniem pragnień. Uzasadnione wydaje się stwierdzenie, że następuje tutaj redukcja pojęcia szczęścia do czegoś bardzo przyziemnego.

Esteta nie posiada wiedzy o sobie jako o podmiocie egzystencji. Z czasem traci on zdolność wybierania tego, czego pragnie, a także kontrolę nad

${ }^{17}$ Zob. K. Toeplitz, Teoria osobowości estetycznej (według Sørena Kierkegaarda), [w:] Aktualność Kierkegaarda. W 150 rocznicę śmierci myśliciela z Kopenhagi, red. A. Szwed, Antyk, Kęty 2006, s. 8.

${ }^{18}$ „Ludzie nie tkwią w [...] stadiach permanentnie. Ich życie jest nieustannym miotaniem się od jednego typu życia do innego" (K. Toeplitz, Kierkegaard, dz. cyt., s. 51). „Egzystencjalnej dialektyki” Kierkegaarda nie cechowała statyczność; do etapu estetycznego można było „powrócić” poprzez swoisty regres egzystencjalny. Oczywiście może się zdarzyć, że człowiek całe swoje życie spędzi nie przechodząc do wyższych etapów (tak jest np. w przypadku osobowości estetycznej). Duński filozof akcentuje jednak mo żli os śc zmiany (zob. K. Toeplitz, Teoria..., dz. cyt., s. 10).

${ }^{19}$ Zob. A. Szwed, dz. cyt., s. 101.

${ }^{20}$ Zob. tamże. 
otaczającą go rzeczywistością. Naraża się na ryzyko bycia zaskoczonym przez świat zewnętrzny, którego nie zna. Każda z możliwości wyboru jawi mu się jako względna; esteta ocenia je przez pryzmat użyteczności. Jak wskazano, podobny stosunek ma do samego siebie - pozostaje dla siebie wielką niewiadomą ${ }^{21}$, nie posiada stałego obrazu siebie (gdyż ulega on zmianie w zależności od podejmowanych czynności). Następuje negacja czasowej ciągłości; znaczenie ma dla niego tylko teraźniejszość.

W efekcie podejmując różne działania esteta osiąga przeciwieństwa swoich założeń ${ }^{22}$. Radość ustępuje miejsca smutkowi i rozczarowaniu, następstwem czego jest rozpacz. Postawienie różnorakiej rozkoszy, przyjemności w centrum życia prowadzi do poczucia bezsensu egzystencji. Nie następuje to jednak od razu.

Życie nieświadome, w którym człowiek poddaje się trendom i staje się bezwzględnym konformistą, sprzyja utracie poczucia podmiotowości i kontroli nad własnym życiem. W pewnym momencie esteta zaczyna rozumieć, że rozkosz stała się zasadą jego życia; paradoksalnie jest to chwila przełomowa, gdyż to od niej rozpoczyna on bardziej świadomą $a^{23}$ egzystencję, sam bowiem (poprzez swoją refleksję) określa ową zasadę. Po chwili od doznania rozkoszy, zaspokojenia pragnień (co stanowi wybór mniejszego dobra, jeśli nie zła), jednostka zaczyna odczuwać nudę. Aby całkowicie nie pogrążyć się w niej, wymyśla coraz dziwniejsze i bardziej wyrafinowane przyjemności ${ }^{24}$.

Takie postępowanie nie pozostaje jednak bez wpływu na stan duchowy i psychiczny człowieka. Jego efektem jest popadnięcie w stan melancholii25, którą Kierkegaard określa jako „histerię ducha”, gdyż jej źródła tkwią właśnie w życiu duchowym ${ }^{26}$. Przejawia się ona w świadomości, że wszelkie

${ }^{21}$ Warto przypomnieć w tym miejscu o akcentowanej przez Kierkegaarda konieczności poznania przez pojedynczego człowieka samego siebie jako warunku rozpoczęcia prawdziwej egzystencji.

${ }^{22}$ Zob. K. Toeplitz, Kierkegaard, dz. cyt., s. 58.

${ }^{23}$ Choć oczywiście ciągle jeszcze nieświadomą - jest to dopiero droga do świadomej egzystencji.

${ }^{24}$ Zob. S. Kierkegaard, Albo - albo, t. 2, przeł. K. Toeplitz, PWN, Warszawa 1982, s. $249-250$.

${ }^{25}$ Zob. tamże, s. 214 i 253.

${ }^{26}$ Zob. tamże, s. 255. 
wartości ziemskie w rzeczywistości nic nie znaczą. Człowiek nie znajduje się jednak jeszcze na etapie, w którym duch pojmuje samego siebie i staje się świadomy; zbliża się jednak do niego, dochodząc do odkrycia, że estetyczny typ egzystencji w gruncie rzeczy jest rozpaczą. Jest to najważniejsza refleksja estety ${ }^{27}$.

Pojawia się także bezprzedmiotowy lęk; jednostka jest czymś zaniepokojona, lecz nie potrafi określić, czym. Ów lęk wypływa z obawy przed uleganiem pożądaniom; powstrzymuje człowieka przed popełnianiem kolejnych grzechów. Już w tym momencie lęk staje się kategorią religijną ${ }^{28}$, mimo że w tym stadium istnienie Boga nie jest jeszcze zauważane. Prowadzi to ostatecznie do osiągnięcia przez jednostkę pewnego dystansu do tego, co ją otacza, a co wcześniej stanowiło dla niej najwyższą wartość. To stawia ją wobec konieczności podjęcia pewnej decyzji, określonej jako „sytuacja albo - albo"29. Nadchodzi moment, w którym trzeba „zrzucić maskę" Jednostka musi wybrać, czy chce nadal trwać w rozpaczy, żyjąc jedynie tym, co doczesne, czy podejmie ryzyko zmiany stosunku do rzeczywistości i siebie samego.

Wraz z pojawieniem się autorefleksji oraz wolności, w życiu człowieka rodzi się coraz większe poczucie zagrożenia, chaosu, czemu towarzyszy psychiczna niestabilność. Mimo to zmierza on w kierunku etycznego samoujawnienia się, poprzez które może podźwignąć się z rozpaczy i dezintegracji. Prowadzi ono do wyjścia z zamknięcia w immanencji świadomości pierwotnej, z okresu bezrefleksyjnej bezpośredniości ${ }^{31}$. Wybór ten, stanowiący skok w novum, jest wreszcie wyborem etycznym, poprzez który człowiek rozpoczyna egzystencję etyczną. W efekcie pojawia się u niego poczucie ciągłości życia, którego tak brakowało estecie. Wyrasta

${ }^{27}$ Zob. A. Szwed, dz. cyt., s. 108.

${ }^{28}$ Zob. K. Toeplitz, Kierkegaard, dz. cyt., s. 59.

${ }^{29}$ Interesujący jest opis sformułowania „albo - albo”, jaki podaje Kierkegaard: „[...] słowa te nie tworzą spójnika rozłącznego, jak twierdzą gramatycy, nie, one należą nierozłącznie do siebie i dlatego muszą być pisane jako jedno słowo. Zwłaszcza, że połączone ze sobą tworzą wykrzyknik, którym zwracam się do ludzkości [...]”: S. Kierkegaard, Albo-albo, t. 2, dz. cyt, s. 212.

${ }^{30}$ Zob. tamże.

${ }^{31}$ Zob. A. Szwed, dz. cyt., s. 112. 
ono przede wszystkim z doświadczenia własnej podmiotowości, co jest wynikiem podjętej decyzji.

Pojawiające się rozumienie własnej egzystencji umożliwia świadome jej kształtowanie. Człowiek etyczny posiada własną teleologię, którą Duńczyk określa jako „wewnętrzną”. Celem człowieka etycznego jest on sam, dokładniej jego jaźń i jej rozwój. Jest to możliwe dzięki odkrytej na nowo wolności ${ }^{32}$. Proces ten prowadzi do osiągnięcia dystansu do świata ${ }^{33}$ (co nie było dostępne na etapie estetycznym). Dopiero spojrzenie na życie, świat i innych ludzi pod kątem etycznym umożliwia dostrzeżenie ich piękna. Piękno owo, co również znamienne, nie ma w sobie nic ze smutku i melancholii, tak mocno powiązanych z estetyką ${ }^{34}$. Teraz jednostka odkrywa samą siebie, uświadamiając sobie, że jest duchem. Jej sposób patrzenia na świat ulega całkowitej przemianie. Dla estety kluczową wartością były rzeczy doczesne, a wszelką bezinteresowność postrzegał jako przeżytek. Dla człowieka etycznego istotne są natomiast inne kwestie, np. obowiązek ${ }^{35}$. Co jednak jeszcze bardziej istotne, do jego życia zostaje wprowadzone pojęcie Boga. U podstaw rozumienia etyki u Kierkegaarda leży bowiem dążenie człowieka do Absolutu. Po raz kolejny widać, że również ten etap jest środkiem do celu, a nie celem egzystencji.

To, co etyczne, jest czymś absolutnie praktycznym, realizowanym w życiu. Jednak postępowanie zawsze jest uwarunkowane przez przyjęte kryteria dobra i zła, i sprowadza się do wyboru między tymi dwoma wartościami. Jakie są kryteria oceny tego, co dobre i złe? Dla Kierkegaarda wypływają one przede wszystkim z wewnętrznego doświadczenia jednostki. Wraz z dokonaniem wyboru to, co etyczne, ujawnia się jako absolutna różnica między dobrem i złem ${ }^{36}$. Kategorie te mogą być zrozumiane

${ }^{32}$ Zob. S. Kierkegaard, Albo - albo, t. 2, dz. cyt., s. 374-375.

${ }^{33}$, „[...] ruch [jaźni] idzie od jednostki ku światu, przez świat i wraca z powrotem do niej. To jest ruch i to rzeczywisty, ponieważ powstaje on w wyniku działania wolności [...]. Jeśli tak właśnie jest, jednostka staje w pewnym sensie ponad stosunkami, w których żyje, z czego wcale nie wynika, że nie żyje w obrębie tych stosunków [...]": tamże, s. 375.

${ }^{34}$ Zob. tamże, s. 377.

${ }^{35}$ Zob. tamże, s. 377-382.

${ }^{36}$ Zob. tamże, s. 300-302. 
i określone tylko dzięki wolności. Właśnie wolność jest tożsama z dobrem ${ }^{37}$. Spełniając czyny dobre jednostka trwa w wolności, a grzesząc - bezpośrednio swoją wolność ogranicza. Życie bez doświadczenia zła to szczęście będące pełnią wolności aktualnej. Etap etyczny polega więc w gruncie rzeczy na przeżyciu swojej wolności ${ }^{38}$.

W stadium etycznym nie można jednak mówić o egzystowaniu w prawdzie. Subiektywne doświadczenie dobra i zła, mimo że istotne i niezwykle cenne, nie stanowi kryterium absolutnego. Domaga się ono głębszego zrozumienia i uzasadnienia. To natomiast jest możliwe dopiero na kolejnym etapie drogi.

Niejednokrotnie postępując w zgodzie z pewnymi zasadami człowiek popada $\mathrm{w}$ konflikt $\mathrm{z}$ innymi. $\mathrm{W}$ ten sposób staje ponownie ${ }^{39}$ wobec perspektywy wewnętrznego konfliktu. Z tej sytuacji istnieje jednak wyjście. Według Kierkegaarda jest nim wiara, która umożliwia swoiste wzniesienie się ponad etykę. Człowiek „stojący w Obliczu Boga” jest zdolny samodzielnie odnaleźć oparcie i uzasadnienie moralności. Musi jednak zrozumieć, że wobec Boga nigdy nie ma racji ${ }^{40}$. Akceptacja tej prawdy nie jest łatwa, ale, jak uważa Kierkegaard, stan, kiedy nie mamy racji, jest niezwykle budujący i pouczający ${ }^{41}$. W ten sposób jednostka wchodzi w najwyższy etap swej egzystencji: etap religijny.

Podjęciu decyzji o oddaniu się Bogu musi towarzyszyć akt skruchy ${ }^{42}$. Oznacza on pokorne uczucie żalu, bólu, jaki jednostka wyraża z powodu obecnego w niej zła. Stanowi jednoznaczne opowiedzenie się po stronie dobra - być może ostatecznie to jest istota wyboru. Zakłada ona przyjęcie Woli Boga bez zbędnych „negocjacji”. W życiu nie jest ważne, ile cierpień i upokorzeń znosi człowiek; kluczowe jest, czy zna swoja winę i odczuwa

${ }^{37}$ Zob. S. Kierkegaard, Pojęcie lęku, przeł. A. Szwed, De Agostini Polska, Warszawa 2002, s. $150 \mathrm{i} \mathrm{n.}$

${ }^{38}$ Zob. A. Szwed, dz. cyt., s. 132.

${ }^{39}$ Taka sytuacja miała miejsce już na etapie estetycznym.

${ }^{40}$ Zob. S. Kierkegaard, Albo - albo, t. 2, dz. cyt., s. 466.

${ }^{41}$ Zob. tamże, s. 468.

${ }^{42}$ Zob. tamże, s. 336-338. 
skruchę $^{43}$. Co istotne, skrucha jest aktem świadomym; jednostka wie, że ponosi osobistą odpowiedzialność za swoje grzechy, a więc za akty wyboru zła.

Człowiek może odnaleźć siebie jedynie w Bogu. Kierkegaard stwierdza, że miłość odczuwaną do Boga da się określić tylko jako skruchę. Wtedy jednostka pozyskuje swoją jaźń, która dotąd znajdowała się jakby poza nią. Poprzez miłość do Boga wyraża bowiem jednocześnie miłość do jaźni i „wybiera ją w sposób absolutny, z ręki wiecznego Ojca”44.

Ostatecznie dopiero wybór Boga, będącego najwyższym dobrem, umożliwia człowiekowi w pełni świadomą i autentyczną egzystencję. Wymusza on specyficzną postawę, która przemienia człowieka z pyszałka, który niegdyś za nic miał wartości moralne, w pokornego sługę Boga. Akt skruchy, dający pełną świadomość własnej winy, ostatecznie doprowadza do rozeznania między dobrem i złem. Następuje zatem kolejna bardzo istotna w myśli Kierkegaarda sytuacja: jednostka poznaje samą siebie (oczywiście nie w sposób absolutny, ale umożliwiający życie w prawdzie). Skrucha jest pewnym odpowiednikiem rozpaczy, która miała miejsce w stadium estetycznym.

Jak wynika z przeprowadzonej analizy, w opinii Kierkegaarda człowiek może podjąć decyzję o zmianie swego życia. To wydaje się jego najistotniejszym przesłaniem a z punktu widzenia tematu tego opracowania.

\section{PROBLEM WOLNOŚCI LUDZKIEJ W MYŚLI BARUCHA SPINOZY}

3.1. ŹRódeA MYŚl I SPINoZy. Bez cienia wątpliwości można stwierdzić, że filozofem, który wywarł niezwykle znaczący wpływ na europejską filozofię XVI i XVII wieku, był René Descartes, zwany Kartezjuszem. Nie bez powodu jest on często określany mianem „ojca nowożytnej filozofii". Jego myśl, której fundamentem był dualistyczny pogląd na świat, znalazła wielu zwolenników i naśladowców; przyczyniła się do stworzenia nowego nurtu filozoficznego. Co zrozumiałe, pojawili się także myśliciele podejmujący z nim polemikę. Jednym z nich był Baruch (Benedykt) Spinoza -

\footnotetext{
${ }^{43}$ Zob. tamże, s. 322.

${ }^{44}$ Tamże, s. 291-292.
} 
Żyd, wykluczony za swoje poglądy z gminy żydowskiej ${ }^{45}$ - twórca monistycznego systemu, który przezwyciężał przeciwstawienie ducha (res cogitans) i materii, ciała (res extensa) ${ }^{46}$. Czerpał on inspiracje z klasycznej metafizyki, szczególnie tej, która przeniknięta była panteistyczną wizją Boga i świata, ujmującą wszelki byt jako przejaw czy emanację bytu absolutnego, Boga ${ }^{47}$.

Nie bez znaczenia były dla Spinozy także refleksje Thomasa Hobbesa, dotyczące problemów ontologicznych, w których negował on co prawda istnienie Boga, lecz popularyzował naturalizm i monizm. Już w tym miejscu warto wspomnieć o poglądach myśliciela na kwestie społeczno-polityczne. Spinoza znany był jako miłośnik wolności i propagator tolerancji. Z pewnością wpływ na to miały wydarzenia $\mathrm{z}$ jego życia, szczególnie usunięcie z gminy żydowskiej, a także poglądy metafizyczne, w których wyrażał konieczność poddania się prawom rządzącym światem i wzywał do wyzbycia się wszelkiego rodzaju „wzruszeń” czy emocji, co miałoby stanowić jedyną prawdziwą drogę, wiodącą do osobliwie pojmowanej wolności.

3.2. KONCEPCJA SUBSTANCJI JAKO ŹRódŁO NEGACJI WOLNOŚCI. W swych rozważaniach ontologicznych Spinoza przyjął definicję substancji rozumianej jako to, co „istnieje samo przez się i samo przez się może być pojęte"48. Warto poddać tę definicję głębszej analizie.

Po pierwsze, wynika z niej, że pojęciu substancji odpowiada coś realnie istniejącego. Nie jest ona czysto umysłowym, abstrakcyjnym konceptem, lecz czymś, co obiektywnie ,jest”. Sposób istnienia substancji jest jednak na mocy tej definicji swoisty i wyjątkowy. Ona sama jest bowiem źródłem swego istnienia - trudno inaczej rozumieć pierwszą część przyjętej przez Spinozę definicji. W tym momencie pojawia się pytanie: co spełnia jej kryteria? Takim bytem może być jedynie Bóg.

Koncepcję Boga i wolności Spinoza przedstawił najpełniej w dziele Etyka w porzadku geometrycznym dowiedziona z 1667 roku. W punkcie trzecim

${ }^{45}$ Zob. S. Nadler, Spinoza, przeł. W. Jeżowski, PIW Warszawa 2002, s. 175-180.

${ }^{46}$ Zob. W. Tatarkiewicz, Historia filozofii, t. 2, Wydawnictwo Naukowe PWN, Warszawa 2007, s. 78.

${ }^{47}$ Przykładem mogą być poglądy Plotyna (zawarte w Enneadach) czy Eriugeny.

${ }^{48}$ B. Spinoza, Etyka, [w:] Traktaty, przeł. I. Halpern-Myślicki, Antyk, Kęty 2003, s. 464. 
pierwszej części przytoczona została powyższa definicja substancji ${ }^{49}$. W następnym punkcie Spinoza przedstawił swoją wizję Boga, pisząc, że jest nim ,jestestwo bezwzględnie nieskończone, składające się z nieskończonej ilości przymiotów, z których każdy wyraża nieskończoną i wieczną treść" ${ }^{50}$.

W tym miejscu myśliciel nie rozmija się jeszcze z żydowską myślą ortodoksyjną. Wyciągnięte przez niego wnioski są jednak bardzo dalekie od teizmu judaistycznego. W twierdzeniu 14 pierwszej części Etyki wskazuje on, że oprócz Boga nie może być dana ani pojęta żadna istota ${ }^{51}$, a więc - istnieje tylko Bóg. Taką tezę można określić jako panteistyczną. Bóg Spinozy jest jednak racjonalny, działa według pewnych praw, które sam stworzył. Wszelki byt (a więc również i człowiek), jako przejaw Boga, podlega tym prawom. Bóg jest sprawczą przyczyną zarówno istnienia bytów, jak i ich treści ${ }^{52}$. Oznacza to, że od Absolutu zależy istota danego bytu, jest ona przez Niego zdeterminowana. W tej koncepcji Bóg nie tylko jest rzeczywiście obecny w bytach materialnych tworzących świat, lecz jest z nimi tożsamy substancjalnie $^{53}$. W odróżnieniu od koncepcji judaistycznych i chrześcijańskich, wedle których Bóg jest transcendentną przyczyną rzeczy, w myśli Spinozy Bóg jest przyczyną immanentną ${ }^{54}$.

Najważniejszą konsekwencją takiej wizji Boga, człowieka i świata jest panteistyczny determinizm. Sam Spinoza podkreśla to, stwierdzając w innym dziele, że wolność przysługuje tylko temu, co istnieje z konieczności swej natury ${ }^{55}$. W tym miejscu warto odwołać się do myśli św. Tomasza z Akwinu, który dokonał podziału bytów na byty przygodne i byt konieczny, którym jest Bóg. Według Spinozy zatem prawdziwie wolny jest jedynie Bóg, który istnieje sam z siebie, Jego bytowanie niejako wynika z Jego natury ${ }^{56}$.

${ }^{49}$ Zob. B. Spinoza, Etyka, [w:] Traktaty, dz. cyt., s. 464.

${ }^{50}$ Tamże, s. 466.

${ }^{51}$ Zob. tamże, s. 474.

${ }^{52}$ Zgodnie z twierdzeniem 25 Etyki (tamże, s. 484).

${ }^{53}$ Zob. S. Kowalczyk, Filozofia wolności, Redakcja Wydawnictw KUL, Lublin 1999, s. 101.

${ }^{54}$ Zob. B. Spinoza, Etyka, [w:] Traktaty, dz. cyt., s. 481.

${ }^{55}$ Zob. B. Spinoza, Traktat krótki o Bogu, człowieku i jego szczęśliwości, [w:] Pisma wczesne, przeł. L. Kołakowski, Warszawa 1969, s. 262.

${ }^{56}$ Zob. S. Kowalczyk, Filozofia..., dz. cyt., s. 101. 
On jest jedyną przyczyną istnienia rzeczy ${ }^{57}$. Twierdzenia 28 i 29 wskazują, że rzeczy są wyznaczone do działania przez Boga (dokładniej przez Jego prawa) i same z siebie nie mogą „znieść” czy „pozbyć się” tego wyznaczenia. Oznacza to, że wszelki byt istniejący w świecie zajmuje z góry ściśle określone miejsce, którego nie jest w stanie zmienić, a także pełni pewne zadania.

W takiej koncepcji nie ma miejsca na klasycznie rozumianą wolność. Prawa Boskie są bowiem wszechobecne, a możliwość wyboru jest czysto iluzoryczna. Potwierdzeniem tych sądów są słowa twierdzenia 29: „we wszechświecie nie ma nic przypadkowego; przeciwnie, wszystko z konieczności natury bóstwa wyznaczone jest do tego, aby w stały sposób istniało i oddziaływało" 58 .

Inną obok determinizmu konsekwencją takiej koncepcji jest panlogizm, czyli pogląd zgodnie z którym wszystkim rządzą prawa logiki; w przypadku koncepcji Spinozy - nadane przez Boga ${ }^{59}$. Skoro jedyną substancją jest rozumny Bóg, to Jego prawa obowiązują powszechnie i koniecznie. Dotyczą wszystkiego, co istniejące, każdego bytu, niezależnie od jego złożoności $\mathrm{i}$ innych cech. W tym momencie pojawia się niezwykle istotne pytanie: jak określić sytuację człowieka w takim świecie?

3.3. CZŁoWIEK W DeterministyczNym śWIECIE - Pyta NIE O MOŻLIWOŚć WYBORU. Jak już powyżej wspominano, nieuchronną konsekwencją założeń, jakie poczynił Baruch Spinoza, jest specyficzna wizja ludzkiej wolności. Jeżeli wszystkim, co istnieje, rządzą absolutne i niezmienne prawa, to czy wszelkie zjawiska, procesy i zachowania, jakie będą mieć miejsce w przyszłości, dają się przewidzieć już teraz? Ta kwestia zajmuje umysły filozofów od wieków i przez cały ten czas powstało wiele koncepcji stanowiących próby odpowiedzi na to pytanie. Niektórzy stali na straży myśli chrześcijańskiej i jej podobnych, uznających wolność człowieka za jedną z największych wartości ${ }^{60}$. Inni z kolei uznawali wolność

${ }^{57}$ Zob. B. Spinoza, Etyka, [w:] Traktaty, dz. cyt., s. 484.

${ }^{58}$ Tamże, s. 486.

${ }^{59}$ Zob. S. Blackburn, Spinoza Benedictus, [w:] Oksfordzki Słownik Filozoficzny, przeł. C. Cieśliński, Książka i Wiedza, Warszawa 2004, s. 374.

${ }^{60}$ Przykładem może być omawiany w następnym rozdziale tej pracy św. Augustyn. 
za fikcję, wymysł ludu. Wskazywali, że gdybyśmy posiadali odpowiednią wiedzę na temat aktualnego stanu rzeczywistości, byłoby dla nas oczywiste, co wydarzy się w nadchodzącej przyszłości. Zachowania i wybory ludzkie byłyby więc niejako z góry określone, co negowałoby wolność woli.

Przykładów myślicieli uznających taką koncepcję było i jest wielu, w tym miejscu dla lepszego zobrazowania poruszanego problemu wystarczy wskazać koncepcję „demona Laplace’a”. Francuski dziewiętnastowieczny fizyk i myśliciel, Pierre Laplace, uznawał (w pewnym uproszczeniu), że jeżeli istniałaby istota posiadająca absolutnie pełną wiedzę dotyczącą stanów cząstek, tworzących to, co rzeczywiste, to byłaby ona w stanie przewidzieć wszystko, co zdarzy się w przyszłości ${ }^{61}$. Jest to koncepcja skrajnie deterministyczna, fatalistyczna; w oczywisty sposób wyklucza wszelką możliwość, zastępując ją absolutną koniecznością. Ma ona także konsekwencje dotyczące antropologii, sprzeciwia się bowiem koncepcji wolności ludzkiej.

Wizja Laplace'a stanowi wyciągnięcie konsekwencji ze specyficznie przezeń pojmowanego panlogizmu. Koncepcja Spinozy, mimo pewnych różnic, wykazuje analogie do pomysłu Laplace'a. O ile bowiem francuski fizyk w punkcie wyjścia przyjął ateizm, o tyle Spinoza wychodzi od panteizmu, uznając, że wszystko, co istniejące, to przejaw jedynej substancji, jaką jest Bóg. Taki monistyczny obraz świata niderlandzkiego myśliciela stoi w oczywistej sprzeczności z personalistyczną koncepcją człowieka ${ }^{62}$. Zanegowana została nie tylko wolność woli (gdyż poprzez monistyczne ujęcie natury ludzkiej zakwestionowano istnienie intelektu i woli ${ }^{63}$ ), lecz także nieśmiertelność duszy i indywidualna osobowość jednostki ludzkiej.

Sam Spinoza, pomimo negacji wolności woli, nie wyrzuca słowa „wolność" ze swego słownika. Łączy ją z koniecznością praw przyrody, które są nadane przez Boga. Uważa, że drogą do osiągnięcia wolności jest dążenie do poznawania mechanizmów natury, co prowadzi człowieka do akceptacji nieuniknionej konieczności, a w konsekwencji daje pożądaną wolnośćc4

${ }^{61}$ Zob. S. Hawking, L. Mlodinow, Wielki Projekt, przeł. J. Włodarczyk, Wydawnictwo Albatros, Warszawa 2011, s. 37-38.

${ }^{62}$ Zob. S. Kowalczyk, Filozofia..., dz. cyt., s. 102.

${ }^{63}$ Tamże, s. 103.

${ }^{64}$ Zob. tamże. 
Jest więc ona pojmowana przez Spinozę w duchu nieco podobnym do stoickiego: jako akceptacja stanu rzeczy, na który człowiek nie ma wpływu ${ }^{65}$. Jak więc w świetle koncepcji Spinozy wygląda „umiejscowienie” człowieka na płaszczyźnie etycznej, między dobrem a złem? Czy człowiek posiada możliwość wyboru między tymi wartościami? Odpowiedź wydaje się jednoznacznie negatywna w świetle wcześniej wspomnianej negacji wolności woli ${ }^{66}$. To dzięki niej bowiem człowiek stając wobec alternatywy może wybrać jedną z możliwości, która jest dobra lub zła sama w sobie albo pociąga za sobą dobre lub złe skutki. .

Wolność polega jednak nie tyle na możliwości dokonywania wyborów, lecz na kierowaniu się w życiu rozumem. Świadczy o tym już sam tytuł części piątej Etyki, który brzmi: 0 mocy rozumu, czyli o wolności ludzkiej ${ }^{67}$. Owa wolność jest osiągalna poprzez walkę ze wzruszeniami (emocjami). Spinoza zwraca jednak uwagę, że rozum nie posiada nad nimi bezwzględnej władzy ${ }^{68}$, dlatego trzeba stosować przeciw nim rozmaite środki zaradcze. Być może więc bardziej trafne od uznania absolutnej negacji ludzkiej wolności u Spinozy byłoby wskazanie na bardzo specyficzny sposób rozumienia tego pojęcia u omawianego myśliciela.

Czy jednak powyższa koncepcja drogi do wolności jest prawdziwa? Warto prześledzić tok rozumowania Spinozy. W twierdzeniu 6 piątej części swej Etyki stwierdza - co zostało już wyżej wspomniane - że człowiek, a dokładniej jego umysł, staje się tym bardziej wolny, im bardziej wszelkie stany rzeczy ujmuje jako konieczne ${ }^{69}$. W przypisie do twierdzenia i dowodu przytoczony zostaje ciekawy przykład, mający być ilustracją postawionej tezy. Spinoza stwierdza w nim, iż nikt nie współczuje niemowlęciu z powodu faktu bycia niemowlęciem. Jest to bowiem naturalny i konieczny etap

${ }^{65} \mathrm{~W}$ pewnych aspektach podobny nurt myślowy reprezentują także niektórzy egzystencjaliści francuscy XX i XXI wieku, np. Comte-Sponville, Rosset etc., wskazując na konieczność akceptacji absurdu ludzkiej egzystencji jako jedynej drogi do radości i szczęścia (zob. J. Russ, Współczesna myśl etyczna, przeł. A. Kuryś, PAX, Warszawa 2006, s. 55-69).

${ }^{66}$ Zob. B. Spinoza, Etyka, [w:] Traktaty, dz. cyt., s. 487.

${ }^{67}$ Tamże, s. 638.

${ }^{68}$ Zob. tamże.

${ }^{69}$ Zob. tamże, s. 643. 
ludzkiego życia, dotyczący każdego. Inaczej byłoby, jak twierdzi myśliciel, gdyby tylko niektórzy rodzili się jako niemowlęta, a pozostali jako dorośli, wtedy bowiem etap niemowlęctwa nie byłby konieczny, gdyż dotyczyłby tylko pewnej części ludzi. Im należałoby się współczucie ze strony innych ludzi ${ }^{70}$. To współczucie jest jedną z emocji, którą Spinoza określa jako wzruszenie. Nie podlega ona kontroli rozumu, sytuuje się niejako ponad nim. A skoro rozum jest źródłem wolności, to łatwo wyprowadzić wniosek, że ograniczające go wzruszenia (emocje) zmniejszają zakres naszej wolności. Właśnie dlatego pojmowanie wszelkich bytów i zjawisk jako koniecznych jest drogą do wolności, gdyż pozwala nam unikać krępujących rozum emocji. O tym specyficznym Spinozjańskim paradoksie będzie mowa w następnym podrozdziale.

3.4. WOLNOŚĆ POPRZEZ UZNANIE DETERMINIZMU. Czy rozumowanie doprowadzające do pojęcia wolności poprzez uznanie jej rzeczywistego braku nie jest paradoksalne? Oznacza ono wszak, że aby osiągnąć wolność, człowiek musi ją uprzednio zanegować. Trudno inaczej określić to, co Spinoza opisuje jako: „zrozumienie wszystkich rzeczy jako koniecznych"71. Jeśli wszystko jest konieczne, to znaczy, że jest z góry zaplanowane. W 29 twierdzeniu z pierwszej części Etyki stwierdza, że w świecie nie istnieją zdarzenia przypadkowe; wszelkie stany rzeczy są bowiem wyznaczone przez Boga ${ }^{72}$, człowiek nie ma na nie najmniejszego wpływu. Przypadek do swego zaistnienia wymaga wolności. Jest on bowiem zawsze zaistnieniem jednej z wielu możliwości, o tych zaś można sensownie mówić jedynie w kontekście wolności.

Spinoza uznaje, że wolność należy pojmować w oderwaniu od ludzkiej czasowości. Wolność jest zdolnością patrzenia na świat rządzący się swoimi prawami z perspektywy wieczności, w oderwaniu od „wzruszeń”, czyli wspominanych uczuć, pragnień czy emocji. Dopiero poznanie motywów własnego postępowania pozwala nam kontrolować rzeczy w takim stopniu, w jakim nasza myśl poprawnie opisuje zdarzenia. ${ }^{73}$. Mamy tu do czynienia ze specyficznie rozumianą jednością rozumu i rzeczywistości.

\footnotetext{
${ }^{70}$ Zob. tamże.

${ }^{71}$ B. Spinoza, Etyka, [w:] Traktaty, dz. cyt., s. 643.

${ }^{72}$ Zob. tamże, s. 486.

${ }^{73}$ Zob. S. Blackburn, Spinoza Benedictus, [w:] Oksfordzki..., dz. cyt., s. 374.
} 
Bez względu na ocenę postawionych przez Spinozę tez, stwierdzić należy pewną koherentność jego rozumowania, którego przyjęcie rodzi jednak poważne konsekwencje natury antropologicznej i etycznej. Stwierdzenie, że wola jest koniecznie przymuszona, a nie wolna, neguje położenie człowieka między wartościami, jakimi są dobro i zło, a także możliwość świadomego podejmowania decyzji i ponoszenia za nie odpowiedzialności.

Niewątpliwie odważne i budzące kontrowersje poglądy Spinozy na problem ludzkiej wolności stanowią jedną z prób odpowiedzi na kluczowe pytania ludzkiej egzystencji - o istnienie i naturę Boga, o wolność człowieka, a także o zło obecne w świecie. Determinizm stanowi jedno z możliwych rozwiązań - pytanie tylko, czy słuszne. Zło wyrządzane człowiekowi przez drugiego człowieka można wytłumaczyć koniecznością, czy jednak takie usprawiedliwianie zła ma coś wspólnego z prawdą? Czy nie prowadzi to do usprawiedliwiania złych uczynków ludzi? Na te pytania trudno znaleźć u Spinozy jednoznaczną odpowiedź, co niewątpliwie świadczy o niedoskonałości jego koncepcji i jej niewystarczających możliwościach wyjaśniających. Wydaje się, że zachwyt wywołany sformułowaniem odpowiedzi na niektóre problemy przysłonił Spinozie fakt, iż owe rozwiązania stały się przyczyną całkiem nowych trudności.

\section{FILOZOFIA WYBORU A PRAWO}

Ukazane poglądy Kierkegaarda i Spinozy stanowią pewien wycinek myśli europejskiej. Filozofowie ci pochodzili z różnych epok: Spinoza tworzył w epoce filozofii nowożytnej, podkreślającej rolę poznania rozumowego, zaś Kierkegaard był dziewiętnastowiecznym przedstawicielem myśli egzystencjalnej. Nic więc dziwnego, że owi filozofie niejednokrotnie bardzo różnili się w swych poglądach na naturę Boga, świata i człowieka. Wybór ich koncepcji jako przedmiotu tego artykułu był celowy, takie zestawienie ukazuje bowiem (oczywiście jedynie fragmentarycznie), w jak różny sposób można postrzegać problematykę ludzkiej wolności.

Kierkegaard przedstawił swoją wizję człowieka, jego egzystencji i relacji do Boga. W jej konstruowaniu uległ pewnym wpływom Georga Wilhelma Friedricha Hegla, z którego poglądami podejmował polemikę. Nie udało mu się uciec od stworzonej przez Niemca słynnej triady: teza - antyteza - synteza. 
Widać to w jego wizji egzystencji ludzkiej ${ }^{74}$. Warto jeszcze raz krótko ją scharakteryzować: człowiek w czasie swojego życia może znajdować się na jednym z trzech etapów (określanych także jako „stadia”), przy czym jego egzystencja staje się $\mathrm{w}$ pełni świadoma dopiero wtedy, gdy $\mathrm{w}$ jego wnętrzu nastąpi zwrot ku Bogu. Jest to pewnego rodzaju synteza dwóch poprzednich okresów egzystencji: estetycznego, w którym człowiek skupiał się na szukaniu przyjemności, a jego życie cechowała bezrefleksyjność, oraz etycznego, w którym podejmował już pewne egzystencjalne rozważania, a przyjemności odsunął na bok, w zamian stosując się do przyjętych zasad etycznych. Ostateczną podstawą i fundamentem ludzkiej egzystencji i jej wolności jest Transcendencja, dlatego wolność człowieka jest formą doświadczenia Boga. Stąd bez odniesienia do wiary człowiek nigdy nie będzie istotą prawdziwie wolną ${ }^{75}$. W ten sposób Kierkegaard dobitnie ukazuje głębokie osadzenie swej myśli w wierze chrześcijańskiej.

Wydaje się, że to właśnie poglądy Kierkegaarda stanowią dobry przykład przyjmowanych przy tworzeniu i egzekwowaniu prawa założeń. Pierwszym z nich jest przyjęcie zdolności człowieka do dokonywania wyborów. To na niej opiera się omówiony „egzystencjalny progres”, w czasie którego podjęta decyzja stanowi zerwanie pewnej dotychczasowej ciągłości i umożliwia zmianę sposobu życia. Jest to założenie niezwykle istotne w naukach prawnych, szczególnie dobrze widoczne w prawie karnym. Istotną funkcją normy prawnej jest odstraszanie, mające zapobiec dokonywaniu przez jednostki określonych wyborów, niekorzystnych z punktu widzenia społeczeństwa $^{76}$. Z drugiej strony, pewnej ochronie podlegają osoby, które z różnych względów nie mogą podejmować decyzji świadomie.

Przykładowo, w prawie karnym osoba niepoczytalna nie ponosi odpowiedzialności karnej za popełnienie czynu zabronionego, w prawie cywilnym zaś zawarte przez nią umowy, których wykonanie mogłoby być dla niej

${ }^{74}$ Oczywiście nie należy tego sformułowania traktować dosłownie; Kierkegaard zaczerpnął tutaj jedynie pewien koncept. Etap etyczny nie stanowi antytezy etapu estetycznego sensu stricto; podobnie jak stadium religijne nie jest jedynie syntezą dwóch poprzednich. Takie przedstawienie ma między innymi zobrazować, że pierwsze dwa etapy mają ostatecznie prowadzić do postawy religijnej.

${ }^{75}$ Zob. S. Kowalczyk, Filozofia..., dz. cyt., s. 188.

${ }^{76}$ Zob. W. Wróbel, A. Zoll, Polskie prawo karne. Część ogólna, Znak, Kraków 2010, s. 43. 
niekorzystne, są uznawane za nieważne. Przyjmujemy bowiem, że wolność była tutaj w istotny sposób ograniczona, w związku z czym nie doszło do dokonania wyboru. Karanie takiej osoby za popełnienie czynu byłoby pozbawione celu (w przypadku prawa karnego), w ramach prawa cywilnego interesy takich osób należy zaś chronić w sposób szczególny.

Również swoista gradacja świadomości, akcentowana przez Kierkegaarda, znajduje w sądach praktyczne zastosowanie. Sąd bowiem, zanim podejmie decyzję $\mathrm{w}$ odniesieniu do konkretnej jednostki, bada nie tylko, czy jest ona winna, lecz także - czy posiadała w danej chwili zdolność w pełni świadomego podjęcia decyzji, czy może działała np. pod wpływem silnego wzburzenia ${ }^{77}$. Podobnie $w$ przypadku stających przed sądami młodych ludzi, całkowicie bezrefleksyjnie podchodzących do swojego życia (a więc, używając terminologii Duńczyka, będących na etapie estetycznym), uznaje się, że nie są jeszcze do końca ukształtowani i w związku z tym stosuje się złagodzony wymiar kary lub zamiast kary orzeka się wobec nich różne środki wychowawcze ${ }^{78}$.

Tego typu przykłady można by mnożyć. Generalnie należy stwierdzić, że w prawie (przynajmniej Polski i innych państw europejskich) istnieje domniemanie wolności woli. Oznacza to, że każdy człowiek odpowiada za swoje czyny, a jedynie na drodze enumeratywnie wyliczonych wyjątków odpowiedzialność może być złagodzona lub wyłączona.

Przyjęcie takiego poglądu byłoby jednak niemożliwe przy zaakceptowaniu wizji rzeczywistości, jaką zaproponował Baruch Spinoza. Jego poglądy z pewnością nie są zgodne z naturalną, ludzką intuicją. U wielu ludzi występuje tendencja do postrzegania siebie jako istoty wolnej. Każdy człowiek uważa siebie za istotę wolną, choć dla każdego ta wolność znaczy coś innego. Tymczasem Spinoza wychodząc od koncepcji substancji i panteizmu

${ }^{77}$ Zob. np. art. $25 \S 3$ Kodeksu karnego („Nie podlega karze, kto przekracza granice obrony koniecznej pod wpływem strachu lub wzburzenia usprawiedliwionych okolicznościami zamachu”) lub art. 148 § k.k. („Kto zabija człowieka pod wpływem silnego wzburzenia usprawiedliwionego okolicznościami, podlega karze pozbawienia wolności od roku do lat 10").

${ }^{78}$ Zob. art. $10 \S 4$ k.k. (,W stosunku do sprawcy, który popełnił występek po ukończeniu lat 17, lecz przed ukończeniem lat 18, sąd zamiast kary stosuje środki wychowawcze, lecznicze albo poprawcze przewidziane dla nieletnich, jeżeli okoliczności sprawy oraz stopień rozwoju sprawcy, jego właściwości i warunki osobiste za tym przemawiają"). 
próbuje udowodnić, że jedyną wolnością, jaka jest dostępna człowiekowi, jest ta wynikająca z akceptacji determinizmu. Do jakich wniosków może prowadzić takie rozumowanie?

Brak wolności przy podejmowaniu decyzji powoduje, że trudne staje się przypisanie jednostce odpowiedzialności za wynikające z decyzji popełnione przez nią czyny, które godzą w powszechnie przyjęte wartości. Tym samym prawo stanowione traci najistotniejszą funkcję, jaką jest normowanie stosunków między jednostkami. Ponieważ nie można ponosić odpowiedzialności za czyny, które są wynikiem działania siły zewnętrznej (tzw. vis absoluta) - a to dotyczyłoby wtedy wszystkich - zasadność istnienia prawa stałaby się nader wątpliwa. Całkowicie nieuzasadnione byłoby stosowanie jakichkolwiek sankcji. Łatwo pojąć, że w tym przypadku byłoby to sprzeczne z zasadą sprawiedliwości, a pewnie zarazem równości. Stosunki społeczne, gospodarcze i ekonomiczne, normowane przez prawo, wobec utraty jego znaczenia uległyby rozpadowi. To zaś w bezpośredni sposób doprowadzić mogłoby do anomii i innych negatywnych zjawisk. Wcielenie koncepcji Spinozy w życie wiodłoby zatem do sytuacji dramatycznych.

Wydaje się więc, że jesteśmy niejako zmuszeni do przyjęcia wizji zdecydowanie bardziej zbliżonej do poglądów Kierkegaarda niż Spinozy. Pojęcie wolnego wyboru jest bowiem bardzo istotne w teorii prawa i to ono sprawia, że istnienie prawa ma jakikolwiek sens. Zgodnie z myślą Spinozy, karanie miałoby sens jedynie o tyle, o ile pomagałoby jednostce $\mathrm{w}$ osiągnięciu stanu nieco podobnego do nirwany - pełnego opanowania uczuć.

Jednym z najciekawszych zagadnień refleksji filozoficzno-prawnej jest problem relacji prawa i moralności. Przyjmując wizję Spinozy, negujemy w pewnym sensie także i etykę. Determinizm czyni bowiem człowieka bezwładnym - nie może on postępować ani źle, ani dobrze. Wybór między dwoma kluczowymi wartościami (dobrem i złem) jest iluzją, niczym więcej. Czy zatem etyka, rozumiana jako pewien zbiór norm postępowania, ma jakiekolwiek znaczenie? Wydaje się, że na to pytanie pada dziwna odpowiedź: myśliciel pogrąża się bowiem w specyficznie rozumianym stoicyzmie, uznając paradoksalnie, że tylko akceptacja braku wolności może przynieść wolność i pokój. 


\section{ZAKOŃCZENIE}

Na koniec warto dokładnie wyeksplikować istotę modeli wolności, które zostały przedstawione $\mathrm{w}$ tej pracy. Dla Kierkegaarda wyraża się ona w możliwości dokonywania wyborów, które doprowadzają człowieka do autentycznego i wartościowego życia. To dzięki wolności człowiek może zmieniać swoje postępowanie i ostatecznie zwrócić się ku Bogu. Właśnie to stanowi o jego wielkości i odróżnia go od zwierząt. Nie bez powodu podczas refleksji nad twórczością filozofa z Kopenhagi na myśl przychodzi słynna Mowa o godności człowieka, autorstwa włoskiego renesansowego myśliciela Giovanniego Pico della Mirandoli ${ }^{79}$. Ukazuje on specyfikę ludzkiej egzystencji, w której człowiek może stawać się równym aniołom, ale także schodzić do poziomu zwierząt, kierujących się tylko instynktem.

U Kierkegaarda człowiek jest wędrowcem, który może zatrzymać się na etapie estetycznym, nie odkrywając głębi życia, ale ma także możliwość zwrócenia się ku Bogu. W tym tkwi istota jego wolności. Za swoje czyny ponosi on odpowiedzialność i właśnie to jest najistotniejsze z punktu widzenia teoretyków i praktyków prawa. Kierkegaard pozostaje więc obecny w pewnym archetypie myślenia, z jakim spotykaliśmy się już w starożytnych cywilizacjach, szczególnie w Rzymie, którego mieszkańcy stworzyli system prawny, do dziś stanowiący fundament prawa prywatnego.

By wskazać, jak bardzo jest to wizja różna od Spinozjańskiej, nie trzeba na nowo przedstawiać poglądów niderlandzkiego myśliciela. Jego model wolności jest zupełnie inny, nie oznacza wolności kształtowania swego życia poprzez samodoskonalenie lub samodegradację, które następują wskutek podejmowanych decyzji. Jest raczej pewną postawą wobec rzeczywistości. Zostało już wskazane, jak bardzo pesymistyczna jest ta koncepcja człowieka i jakie konsekwencje z niej wypływają. Wydaje się, że sam Spinoza miał pewne problemy z „dopasowaniem” swojej wizji do rzeczywistości; niewystarczająco wyjaśniał wynikające z niej konsekwencje. Łatwo jednak dostrzec, do jak tragicznych rezultatów można by dojść, kierując się w praktyce jego myślą.

Nie jesteśmy oczywiście w stanie sprawdzić, który z nurtów, reprezentowanych przez omówioną dwójkę myślicieli, jest bliższy prawdy. Być

${ }^{79} \mathrm{G}$. Pico della Mirandola, Oratio de hominis dignitate. Mowa o godności człowieka, przeł. Z. Nerczuk, M. Olszewski, IF iS PAN, Warszawa 2010. 
może większość z nas tkwi w pewnej iluzji wolności? Możliwe, że rzeczywiście jesteśmy „mózgami w naczyniu”, by posłużyć się analogią do Hilary’ego Putnama $^{80}$. Na to pytanie nie możemy jednoznacznie odpowiedzieć. I właśnie w tym miejscu pojawia się zasadnicza różnica między filozofią a naukami prawnymi: o ile w tej pierwszej zakładanie czegokolwiek „,z góry” jest postrzegane negatywnie, o tyle w prawie staje się koniecznością.

\section{KIERKEGAARD'S AND SPINOZA'S PHILOSOPHY OF CHOICE AND THE THEORY OF LAW}

\section{SUMMARY}

Lawyers who deal with applying law in practice very often are not aware of many hidden suppositions, which justify the existence of law and make it reasonable. It is obvious that in discovering them philosophy can be helpful. The main part of this article is the analysis of the thought of two European philosophers: S. Kierkegaard and B. Spinoza. The important field of their interest was a philosophy of human existence. Its significant element is liberty. The attitude to it creates their visions of being.

Kierkegaard is well known as the author of „three periods of human life (esthetical, ethical and religious)" concept. In his opinion the necessary element of any progress in existence is taking the plunge and changing the way of life. It is possible by dint of liberty. A totally different vision can be found in Spinosa'a "Ethics more geo-metrico". The author wants to convince us that the potentiality of making decisions is only an illusion.

The possible consequences of the acceptance of such a vision were shown very briefly; the goal of the paper is also to demonstrate that since the beginning of our civilisation we have had to assume a concept similar to Kierkegaardian's.

\section{KEYWORDS}

criminal law, determinism, free will, God, philosophy of choice, theory of law, Kierkegaard S., Spinoza B.

${ }^{80}$ Zob. H. Putnam, Mózgi w naczyniu, [w:] Wiele twarzy realizmu i inne eseje, przeł. A. Grobler, PWN, Warszawa 1998, s. 295-324. 